\title{
Enhanced Susceptibility to Kainate-Induced Seizures, Neuronal Apoptosis, and Death in Mice Lacking Gangliotetraose Gangliosides: Protection with LIGA 20, a Membrane-Permeant Analog of GM1
}

\author{
Gusheng Wu, Zi-Hua Lu, Jianfeng Wang, Yvette Wang, Xin Xie, Markus F. Meyenhofer, and Robert W. Ledeen \\ Department of Neurology and Neurosciences, New Jersey Medical School, University of Medicine and Dentistry of New Jersey, Newark, New Jersey 07103
}

\begin{abstract}
Knock-out (KO) mice lacking gangliotetraose gangliosides attributable to disruption of the gene for GM2/GD2 synthase [GalNAcT (UDP- $N$-acetylgalactosamine:GM3/GD3 $\beta$-1,4- $N$-acetylgalactosaminyltransferase; EC 2.4.1.92)] are revealing key neural functions for the complex gangliosides of brain. This study has found such animals to be highly susceptible to kainic acid (KA)-induced seizures in terms of both seizure severity and duration. Intraperitoneal injection of $25 \mathrm{mg} / \mathrm{kg} \mathrm{KA}$ produced status epilepticus for $\sim 200 \mathrm{~min}$ in normal mice or heterozygotes and more than four times longer in the KO mice. The latter group suffered $\sim 30 \%$ mortality, which increased to $\sim 75 \%$ at dosage of $30 \mathrm{mg} / \mathrm{kg} \mathrm{KA}$, compared with $10-14 \%$ for the other two genotypes at the latter dosage. Nissl staining and terminal deoxynucleotidyl transferase-mediated biotinylated UTP nick end labeling assay revealed substantial deterioration of pyramidal neurons attributable to apoptosis in the KO hippocampus, especially the CA3 region. Seizure activity in the KO mouse was only moderately diminished by intraperitoneal injection of GM1 ganglioside, whereas LIGA 20, a semisynthetic analog of GM1, substantially reduced both seizure severity and cell damage. The potency of LIGA 20 was correlated with its enhanced membrane permeability (compared with GM1), as seen in the increased uptake of $\left[{ }^{3} \mathrm{H}\right]$ LIGA 20 into the subcellular fractions of brain including cell nuclei. The latter finding is consonant with LIGA 20-induced restoration of the $\mathrm{Na}^{+} / \mathrm{Ca}^{2+}$ exchanger located at the inner membrane of the nuclear envelope in $\mathrm{KO}$ mice, an exchanger dependent on tight association with GM1 or its analog for optimal activity. These results point to a neuroprotective role for GM1 and its associated exchanger in the nucleus, based on regulation of $\mathrm{Ca}^{2+}$ flux between nucleoplasm and nuclear envelope.
\end{abstract}

Key words: epilepsy; ganglioside GM1; ganglioside knock-out mouse; kainate-induced seizures; LIGA 20; nuclear calcium; nuclear sodium-calcium exchanger; sodium-calcium exchanger

\section{Introduction}

Among the several gangliotetraose molecular forms that comprise the major ganglioside family in the CNS, GM1 has received considerable attention because of its diverse neurophysiological functions (Ledeen et al., 1998). This monosialoganglioside contains an oligosaccharide chain of five sugars attached to ceramide, the membrane-anchoring moiety (Fig. $1 A$ ). Alterations of $\mathrm{Ca}^{2+}$ flux at the plasma membrane (PM) and within the cell are among the GM1 functions that have been demonstrated in a variety of systems (for review, see Ledeen and $\mathrm{Wu}, 2002$ ). In keeping with those findings, cultured CNS neurons from genetically altered mice lacking GM1 and other $N$-acetylgalactosamine(GalNac)containing gangliosides because of disrupted GM2/GD2 synthase [UDP- $N$-acetyl-D-galactosaminyltransferase (GalNAcT); EC 2.4.1.92] (Fig. $1 B$ ) suffered dysregulation of $\mathrm{Ca}^{2+}$ homeostasis

\footnotetext{
Received April 29, 2005; accepted 0ct. 2, 2005.

This work was supported by National Institutes of Health Grant NS033912.

Ganglioside nomenclature is that of Svennerholm (1964).

Correspondence should be addressed to Dr. Robert Ledeen, Department of Neurology and Neuroscience, MSB-

H506, New Jersey Medical School, 185 South Orange Avenue, Newark, NJ 07103. E-mail: ledeenro@umdnj.edu.

DOI:10.1523/JNEUROSCI.3635-05.2005

Copyright $\odot 2005$ Society for Neuroscience ～0270-6474/05/2511014-09\$15.00/0
}

(Wu et al., 2001a). The apoptotic effect of this dysregulation in cultured CNS neurons, induced by both glutamate and high $\mathrm{K}^{+}$, was partially attenuated by GM1 and more effectively by LIGA 20 , a semisynthetic analog of GM1 (Fig. 1A) (Wu et al., 2004). These findings agreed with the previous studies of Costa et al. (Favaron et al., 1988; De Erausquin et al., 1990; Manev et al., 1990, 1993), who introduced the LIGA-type derivatives and demonstrated their superior neuroprotective action in neuronal cell cultures . The studies of Wu et al. (2001b, 2004) highlighted an important physiological difference between these glycolipids, LIGA 20 showing enhanced capability to enter cells and insert into the nuclear envelope (NE) as well as the PM, in contrast to GM1, which merely inserted into the PM under similar conditions. It thus appeared that LIGA 20 restored a defective nuclear process in the $\mathrm{KO}$ mouse normally mediated by GM1. The latter ganglioside was shown to occur naturally in the NE and to increase there during axonogenesis (Wu et al., 1995a). Its function at that site was suggested to involve regulation of nuclear $\mathrm{Ca}^{2+}$ (Wu et al., 1995b), and this received strong support in the subsequent demonstration that GM1 modulates nuclear $\mathrm{Ca}^{2+}$ through tight association with $\mathrm{Na}^{+} / \mathrm{Ca}^{2+}$ exchanger in the NE whose activity it potentiates (Xie et al., 2002). 
A

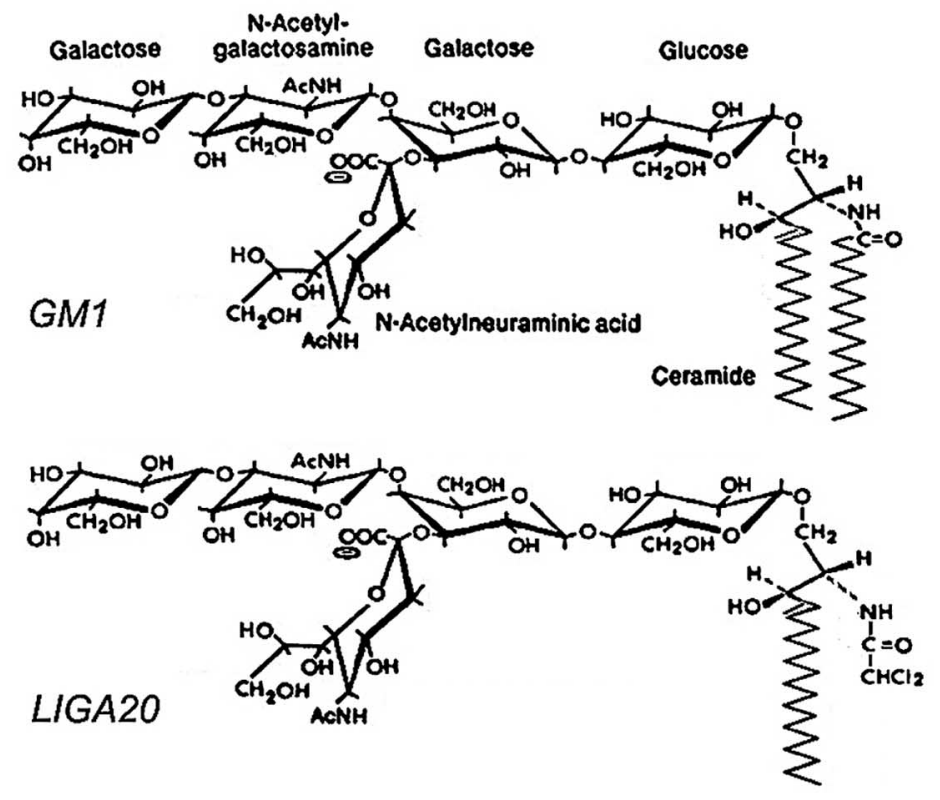

B

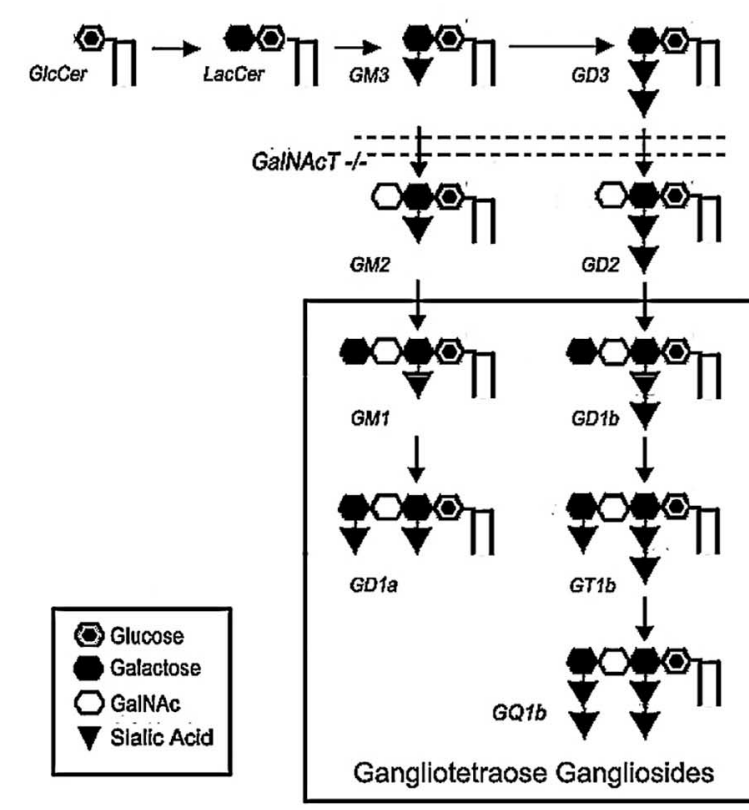

Figure 1. Ganglioside structures and biosynthetic pathways. $A$, Detailed structures of GM1 and LIGA 20. The latter contains altered ceramide structure in which the long-chain fatty acid (18:0) is replaced by dichloroacetate; sphingosine and oligosaccharide chains are the same as GM1. B, Biosynthetic sequences for gangliotetraose gangliosides, in addition to GM3, GM2, GD3, and GD2. The dashed line shows biosynthetic steps eliminated in GaINAcT ${ }^{-1-} \mathrm{KO}$ mice.

To determine whether such calcium modulatory activity can be observed in vivo we have studied kainate (KA)-induced epileptogenesis in the above gangliotetraose-null KO mouse. Calcium dysregulation as a feature of excitotoxic neuronal injury has been well characterized in this widely used model of status epilepticus (Meldrum and Garthwaite, 1990; Choi, 1994; Ben-Ari and Cossart, 2000). This results from activation of specific glutamate receptors with resultant elevation of intracellular $\mathrm{Ca}^{2+}$. The CA3 region of the hippocampus in rodents is especially vulnerable to KA, injected either systemically or intracerebrally. Seizure activity originating in that area propagates to other limbic structures with accompanying neuronal loss characteristic of that occurring in patients with temporal lobe epilepsy (Nadler, 1981; Ben-Ari and Cossart, 2000). The ability of endogenous ganglioside to inhibit epileptogenesis was suggested in a recent report of a child with mutated GM3 synthase who suffered infantile-onset symptomatic epilepsy syndrome (Simpson et al., 2004). A similar conclusion emerged from the present study in which the abovementioned gangliotetraose-null KO mouse showed greatly enhanced susceptibility to $\mathrm{KA}$, consistent with $\mathrm{Ca}^{2+}$ dysregulation and loss of neuroprotective function. Attenuation of seizure activity and neuron destruction by LIGA 20 pointed to a key role for GM1 in maintaining $\mathrm{Ca}^{2+}$ homeostasis. The greater efficacy of this derivative, compared with GM1 itself, after intraperitoneal administration was attributed to its membrane permeant properties that facilitated CNS and cellular entry followed by insertion into the NE. Its function there was suggested to be potentiation of the $\mathrm{Na}^{+} / \mathrm{Ca}^{2+}$ exchanger, a normal function of the missing GM1. Some of these findings were presented in a preliminary communication (Ledeen et al., 2004).

\section{Materials and Methods}

Animals and seizure induction. A breeding pair of heterozygotes (HZTs) with disrupted gene for GM2/GD2 synthase (UDP-N-acetyl-D-galactosamine:GM3/GD3 N-acetyl-D-galactosaminyltransferase, GalNAcT;
EC 2.4.1.92; C57BL/6 background), originally produced by Dr. Richard Proia and coworkers (Liu et al., 1999a), was kindly provided by Dr. Ronald Schnaar (Departments Pharmacology and Neuroscience, Johns Hopkins University School of Medicine, Baltimore, MD). Heterozygous male and KO or HZT female offspring from this pair were used to produce more breeders. Knock-out females in each generation were backcrossed with wild-type (WT) C57BL/6 males, and resulting F1 HZT males were used for additional reproduction. Animals were maintained in the University of Medicine and Dentistry of New Jersey animal facility with $12 \mathrm{~h}$ light/dark cycles. They were genotyped by PCR analysis as described previously (Wu et al., 2001a). All animal procedures were in accordance with the National Institutes of Health Guide for the Care and Use of Animals and approved by the local animal care committee.

Seizures were induced by intraperitoneal administration of mice 13-15 weeks of age with kainic acid (KA) (25 or $30 \mathrm{mg} / \mathrm{kg}$ ) in PBS. Control animals received saline only. Seizures were recorded by video camcorder and scored as described (Liu et al., 1999b; Buckmaster et al., 2002) at the following stages: 0 , no abnormality; 1 , exploring, sniffing, and grooming ceased, becoming motionless; 2 , forelimb and/or tail extension, appearance of rigid posture; 3 , myoclonic jerks of the head and neck, with brief twitching movement, or repetitive movements with head bobbing or "wet-dog shakes"; 4 , forelimb clonus and partial rearing, or rearing and falling; 5 , forelimb clonus, continuous rearing and falling; 6 , tonic-clonic movements with loss of posture tone, often resulting in death. Time of seizure initiation (from KA injection to more than or equal to stage 3), seizure duration, maximum seizure intensity, and seizure scores at various times were analyzed (one-way ANOVA with Dunnett's post test; GraphPad Prism software). In trials using exogenous LIGA 20 or GM1, animals were injected intraperitoneally with designated dose $2 \mathrm{~h}$ before KA injection.

Anatomical pathology. Seven days after KA treatment, animals were anesthetized with phenobarbital and transcardially perfused with $4 \%$ paraformaldehyde in PBS, pH 7.2. The brains were removed and postfixed in the same solution at $4^{\circ} \mathrm{C}$ for at least $24 \mathrm{~h}$, and then transferred to $30 \%$ sucrose for $2-3 \mathrm{~d}$ at $4^{\circ} \mathrm{C}$. Coronal frozen sections $(20-30 \mu \mathrm{m}$ thick) through hippocampus were prepared and stained with cresyl violet (Nissl) for evaluation of general neuronal morphology (Liu et al., 1999b; Buckmaster et al., 2002), and transferase-mediated biotinylated UTP 
nick end labeling (TUNEL) (Apoptag Plus Fluorescein in situ, Apoptosis Detection Kit from Intergen, Purchase, NY) was used for determination of apoptosis (Wu et al., 2001a). Neuronal damage in the hippocampus was scored in five to six adjacent brain sections and subjected to semiquantification as described previously (Liu et al., 1999b): 0, no damage; 1, occasional neuron injury; 2, small number of neurons $(<10 \%)$ damaged or dead; 3 , larger number of neurons (10-50\%) damaged or dead; 4 , extensive neurons $(>50 \%)$ lost and dead. Differences between groups were assessed with one-way ANOVA with Dunnett's post test.

Incorporation of GM1 and LIGA 20 into brain membranes. ${ }^{3} \mathrm{H}$ labeling of GM1 and LIGA 20 in the terminal galactose was effected with the galactose oxidase- $\mathrm{NaBH}_{4}$ procedure (Leskawa et al., 1984) and the products purified by reversephase chromatography through a C18 Sep-Pak cartridge (Millipore, Bedford, MA) (Ledeen and $\mathrm{Yu}, 1982$ ). Five to six WT mice $13-15$ weeks of age were injected intraperitoneally with $\left[{ }^{3} \mathrm{H}\right] \mathrm{GM} 1$ or $\left[{ }^{3} \mathrm{H}\right]$ LIGA $20(15 \mathrm{mg} / \mathrm{kg}, 2.2 \times$ $10^{6} \mathrm{dpm}$ per animal). Two hours after injection, animals were anesthetized and perfused through the heart with $25 \mathrm{ml}$ of warm PBS containing $2 \%$ novocaine and $1000 \mathrm{IU} / \mathrm{ml}$ heparin to completely remove blood. Brain cortices were removed, cut into $1-2 \mathrm{~mm}$ slices, and quickly frozen at $-80^{\circ} \mathrm{C}$ for $30 \mathrm{~min}$. After thawing, the sections were squeezed through a metal mesh (pore size, $70 \mu \mathrm{m}$ ) and dispersed with Dounce homogenizer in buffered $0.3 \mathrm{~m}$ sucrose containing $20 \mathrm{~mm}$ Tris- $\mathrm{HCl}, \mathrm{pH} 7.5,1 \mathrm{~mm}$ $\mathrm{MgCl}_{2}$, and $1 \mathrm{~mm}$ dithiothreitol. The resulting homogenate was centrifuged at $2000 \times g$ for 10 min, giving a pellet of crude nuclei and a supernatant. From the former, pure nuclei were isolated by gradient centrifugation through $1.8 \mathrm{M}$ sucrose at $100,000 \times g$ for $90 \mathrm{~min}$ (Wu et al., 1995a). Supernatant from the above $2000 \times g$ centrifugation was recentrifuged at $18,000 \times g$ for $15 \mathrm{~min}$ to give a crude mitochondria pellet, and supernatant from that was further centrifuged at $100,000 \times g$ for 90 min to give a microsomal pellet and supernatant. All subcellular fractions and initial homogenate were dispersed in small volumes of PBS, and lipids were extracted with $10 \mathrm{vol}$ of chloroform/methanol (1:1, v/v). Gangliosides in the extract were separated with Folch partitioning (Folch et al., 1957), followed by chromatography through C18 Sep-Pak cartridge (Ledeen and $\mathrm{Yu}, 1982$ ). Purified gangliosides were dried under $\mathrm{N}_{2}$ stream, dissolved in chloroform/methanol $(1: 1, \mathrm{v} / \mathrm{v})$ and mixed with unlabeled bovine brain gangliosides. In experiments with $\left[{ }^{3} \mathrm{H}\right]$ LIGA 20 , unlabeled LIGA 20 was also applied. The samples were separated on a glass-backed high-performance thin-layer chromatography plate coated with silica gel 60 (Wu et al., 2001a) and ganglioside bands visualized with iodine vapor. Areas with GM1 or LIGA 20 were scraped and radioactivity (in disintegrations per minute) determined with a TriCarb 2100 liquid scintillation analyzer (PerkinElmer, Wellesley, MA); counts were normalized with respect to protein content in each fraction. The experiments were repeated three times $(n=3)$, and the counts for $\left[{ }^{3} \mathrm{H}\right] \mathrm{GM} 1$ and $\left[{ }^{3} \mathrm{H}\right]$ LIGA 20 in each fraction were statistically compared using the Student's two-tailed $t$ test.

Incorporation of unlabeled LIGA 20 into brains of KO mice was studied chemically and histochemically. Animals were injected with LIGA 20 $(15 \mathrm{mg} / \mathrm{kg})$, perfused, and brain gangliosides isolated as above. Wild-type and KO mice without LIGA 20 were similarly processed for comparison. In these experiments, isolated gangliosides were not mixed with ganglioside standards before TLC. Resorcinol spray was used to reveal all gan- gliosides; cholera toxin B subunit (Ctx B) linked to horseradish peroxidase (HRP) after neuraminidase treatment was used to detect gangliotetraose gangliosides (Wu and Ledeen, 1988). For histochemical detection of LIGA 20, coronal sections of hippocampus were incubated with Ctx B-HRP ( $2 \mu \mathrm{g}$ Ctx B equivalent per milliliter) in PBS-2\% fetal bovine serum albumin- $0.2 \%$ saponin overnight in a moist chamber at room temperature. HRP reaction was performed with diaminobenzidine (Wu et al., 2004).

$\mathrm{Na}^{+} / \mathrm{Ca}^{2+}$ exchanger activity in isolated nuclei. Nuclei were isolated as described previously (Wu et al., 1995a) from brains of WT and KO mice and $\mathrm{KO}$ mice injected intraperitoneally with LIGA $20(15 \mathrm{mg} / \mathrm{kg}) 2 \mathrm{~h}$ before the mice were killed. Protease inhibitor cocktail (Sigma, St. Louis, $\mathrm{MO}$ ) was included in buffers throughout the procedure. $\mathrm{Na}^{+}$-driven ${ }^{45} \mathrm{Ca}^{2+}$-uptake into nuclear envelope was performed as described previously (Xie et al., 2002). Briefly, $\mathrm{Na}^{+}$was loaded into NE lumen by incubating nuclei with monensin and nigericin in Tris buffer (20 mM), $\mathrm{pH}$ 7.2, containing $150 \mathrm{~mm} \mathrm{NaCl} .{ }^{45} \mathrm{Ca}^{2+}$ uptake was initiated by suspending the nuclei in warm $\left(37^{\circ} \mathrm{C}\right)$ Tris buffer containing $\sim 1 \mu \mathrm{M}$ free $\mathrm{Ca}^{2+}(2$ $\mu \mathrm{Ci} / \mathrm{ml})$ and varied ratios of choline $/ \mathrm{NaCl}(\mathrm{NaCl}$ plus choline $\mathrm{Cl}=150$ $\mathrm{mm}$ ). Uptake occurred for $15 \mathrm{~s}$ and was terminated by rapid filtration through Millipore membrane followed by two rinses with cold Tris buffer containing $\mathrm{LaCl}_{3}$ and EGTA. Nuclei treated with cold citric acid to remove the outer nuclear membrane of the NE (Gilchrist and Pierce, 1993) were used for background determination. ${ }^{45} \mathrm{Ca}^{2+}$ trapped in the $\mathrm{NE}$ was counted, corrected by subtracting background, converted to 
Kainic Acid 25 mg/kg

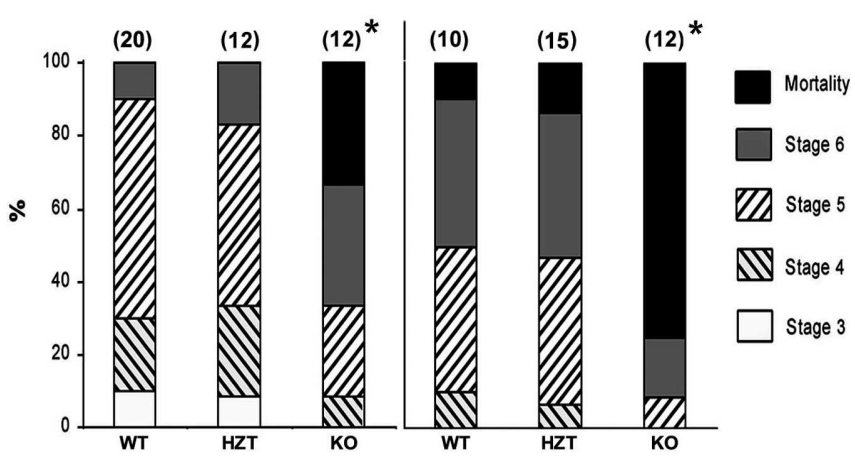

Figure 3. Susceptibility of K0 mice to KA. Young adult mice, 13-15 weeks of age, were injected intraperitoneally with $\mathrm{KA}$ at 25 or $30 \mathrm{mg} / \mathrm{kg}$; the highest seizure score attained by each group within $3 \mathrm{~h}$ after injection is indicated. The number of mice used is given at the top of each bar. KO mice (GalNACT ${ }^{-}{ }^{-}$) were significantly more susceptible to KA-induced seizures, as indicated in higher mortality and severity. ${ }^{*} p<0.01$ compared with WT (one-way ANOVA with Dunnett's post test).

nanomoles $(1 \mathrm{nmol}=1760 \mathrm{dpm})$, and normalized to protein content. The experiments were repeated three times, each in triplicate, and the data were analyzed by the Student's two-tailed $t$ test.

\section{Results}

Susceptibility of GM1-deficient knock-out mice to

KA-induced seizures

The KO mice used in this study with disrupted GalNAcT gene (Liu et al., 1999a) were deficient in all gangliotetraose gangliosides, as revealed by resorcinol spray (Fig. $2 A$ ) and Ctx B overlay (Fig. 2B). They showed compensating elevation of GD3 and GM3, both of which are relatively minor compared with gangliotetraose species in brain of WT mice. Absence of GM1 in KO brain was also shown histochemically with Ctx B-HRP (Fig. 2C).

Kainate administered intraperitoneally at the lower dose (25 $\mathrm{mg} / \mathrm{kg}$ ) caused mortality in $\sim 30 \%$ of KO mice, in contrast to WT and HZT mice that suffered no mortality by $3 \mathrm{~h}$ after injection
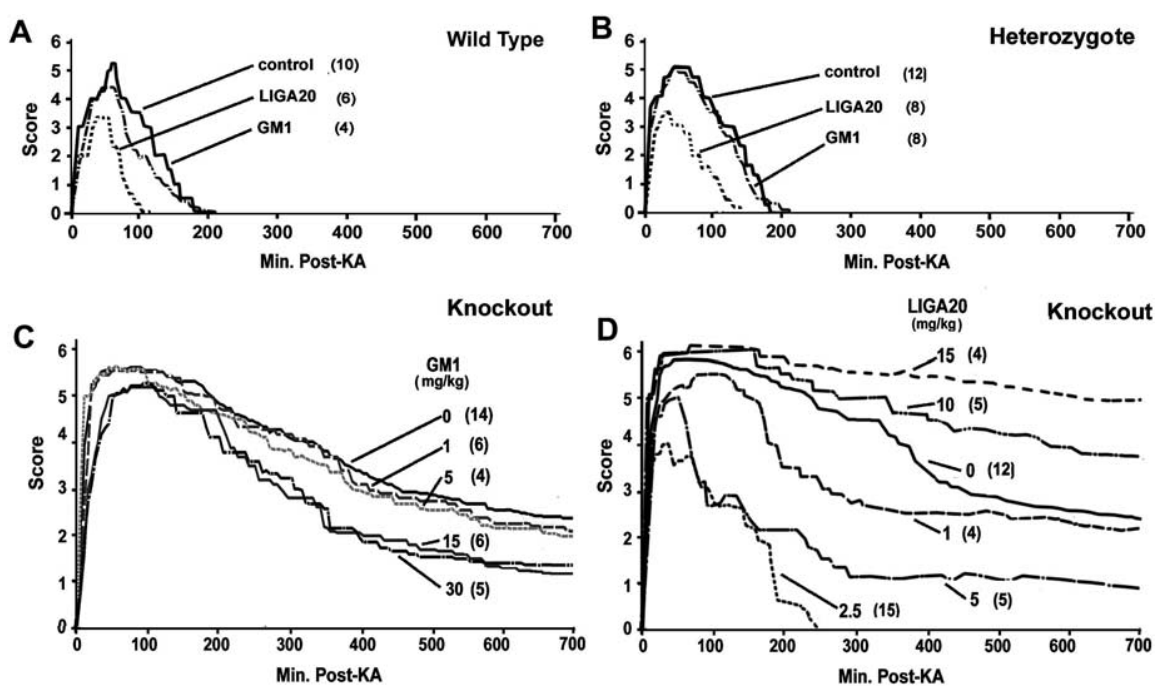

Figure 4. Effect of GM1 and LIGA 20 on KA-induced seizures. Mice were injected intraperitoneally with variable amounts of GM1 or LIGA 20 at $2 \mathrm{~h}$ before $\mathrm{KA}(25 \mathrm{mg} / \mathrm{kg}$ ). Animals that died during the experiment were assigned stage 6 . GM1 was marginally protective at $15 \mathrm{mg} / \mathrm{kg}$ for WT $(\boldsymbol{A})$ and moderately protective toward K0 at 15 or $30 \mathrm{mg} / \mathrm{kg}$ (C). LIGA 20 was significantly protective at $15 \mathrm{mg} / \mathrm{kg}$ toward WT $(\boldsymbol{A})$ and HZT $(\boldsymbol{B})$ and at $2.5 \mathrm{mg} / \mathrm{kg}$ toward KO (D). LIGA 20 doses of 1 and $5 \mathrm{mg} / \mathrm{kg}$ were somewhat less effective for $\mathrm{K} 0$, whereas doses of 10 and $15 \mathrm{mg} / \mathrm{kg}$ enhanced the toxicity of $K A(D)$. The numbers in parentheses indicate the number of mice in each treatment. Detailed data are given in Tables 1 and 2.
(Fig. 3). Seizure severity was also somewhat greater for the KOs whose maximum scores averaged 5.7 during the first $100 \mathrm{~min}$ after KA, in contrast to scores of 5.1-5.3 for WT and HZT; the latter two returned to baseline within another $100 \mathrm{~min}$ (Fig. 4, Table 1), in contrast to the KOs, which continued seizuring with average scores of 3.3 and 2.6 at 400 and 600 min after KA, respectively (Fig. 4, Table 2). At the higher dose of KA (30 mg/kg), mortality of the $\mathrm{KO}$ group rose to $\sim 75 \%$ during the $3 \mathrm{~h}$ period, compared with 10 and $14 \%$ for WT and HZT, respectively (Fig. 3).

\section{Relative efficacy of GM1 and LIGA 20 in rescuing mice from KA-induced seizures}

Intraperitoneal administration of LIGA 20 (15 mg/kg) $2 \mathrm{~h}$ before $\mathrm{KA}(25 \mathrm{mg} / \mathrm{kg})$ reduced both the duration and severity of seizures in WT and HZT, in contrast to GM1 (15 mg/kg), which had no significant effect (Fig. $4 A, B$ ). GM1 at doses $<15 \mathrm{mg} / \mathrm{kg}$ and $>15$ $\mathrm{mg} / \mathrm{kg}$ also had no effect (data not shown). A similar protocol with LIGA 20 applied to KO mice produced pronounced reduction of seizure duration and severity, these mice being restored to a recovery pattern characteristic of the other genotypes (Table 2, Fig. $4 D$ ). In this case, higher doses of GM1 did show a modest but still significant effect in terms of seizure score at 200 and $600 \mathrm{~min}$ after KA (Table 2, Fig. 4C). Untreated KOs showed status epilepticus at stage 4.9-5.7 for $200 \mathrm{~min}$ followed by gradual decline; activity remained $>2.0$ at $700 \mathrm{~min}$ (Fig. 4C,D). Dosage of LIGA 20 proved critical, optimal being $2.5 \mathrm{mg} / \mathrm{kg}$ (Fig. $4 D$ ); $5 \mathrm{mg} / \mathrm{kg}$ was somewhat less effective, whereas $1 \mathrm{mg} / \mathrm{kg}$ had only marginal effect. Doses of 10 and $15 \mathrm{mg} / \mathrm{kg}$ showed added toxicity (Fig. 4D, Table 2) with increased mortality (data not shown). Such LIGA 20 toxicity occurred only in the KOs when coapplied with KA; LIGA 20 alone was not lethal to KOs, even when administered repeatedly at $15 \mathrm{mg} / \mathrm{kg}$ over $3 \mathrm{~d}$, nor was it detrimental to WT or HZT when administered in conjunction with KA.

\section{Attenuation of KA-induced apoptosis in hippocampus by LIGA 20}

Neuronal damage was evaluated in coronal brain sections of surviving mice $7 \mathrm{~d}$ after $\mathrm{KA}$ administration (25 kg/mg). Low-power images of Nisslstained hippocampus sections revealed extensive damage, evident in the indicated $\mathrm{CA} 3$ regions of $\mathrm{KO}$ mice that was substantially attenuated by intraperitoneally administered LIGA 20 (Fig. 5A); less damage was observed in CA1 and that also appeared reduced by LIGA 20. Wild-type mice showed significantly less KA damage in both regions, and this was also diminished by LIGA 20. Higher-power images of the Nissl-stained CA3 region of KO hippocampus after KA revealed shrunken cell bodies and pyknotic nuclei characteristic of injured neurons (Fig. 5B). TUNEL analysis of the same region indicated widespread apoptosis that was significantly reduced by LIGA 20 (Fig. 5C). Semiquantitative analysis of the above phenomena confirmed the major benefit of LIGA 20 pretreatment in reducing KA-induced neuronal damage in all three genotypes (Fig. 5D); for KOs, the average score was reduced from 2.82 to $1.0(p<0.001)$. Preadministration of GM1 following a 
Table 1. Statistical analysis of KA-induced seizures in normal and heterozygote mice

\begin{tabular}{|c|c|c|c|c|c|c|c|c|}
\hline \multirow[b]{2}{*}{ Ganglioside (mg/kg) } & \multirow[b]{2}{*}{$n$} & \multirow{2}{*}{$\begin{array}{l}\text { Initiation } \\
\text { (min) }\end{array}$} & \multirow{2}{*}{$\begin{array}{l}\text { Duration } \\
\text { (min) }\end{array}$} & \multirow{2}{*}{$\begin{array}{l}\text { Maximum } \\
\text { seizure score }\end{array}$} & \multicolumn{4}{|c|}{ Seizure score after KA (min) } \\
\hline & & & & & 100 & 200 & 400 & 600 \\
\hline \multicolumn{9}{|l|}{ Wild type } \\
\hline Control & 10 & $12 \pm 4.8$ & $192 \pm 30$ & $5.3 \pm 1.2$ & $3.5 \pm 1.1$ & 0 & 0 & 0 \\
\hline GM1 (15) & 4 & $15 \pm 6.4$ & $188 \pm 41$ & $4.4 \pm 1.4$ & $2.0 \pm 1.1$ & 0 & 0 & 0 \\
\hline LIGA20 (15) & 6 & $33 \pm 10^{*}$ & $105 \pm 27^{*}$ & $3.3 \pm 0.8^{* *}$ & $0.2 \pm 0.4^{*}$ & 0 & 0 & 0 \\
\hline \multicolumn{9}{|l|}{ Heterozygote } \\
\hline Control & 12 & $7.5 \pm 5.4$ & $228 \pm 54^{* * *}$ & $5.1 \pm 1.0$ & $3.8 \pm 1.5$ & $0.4 \pm 0.6^{* * *}$ & 0 & 0 \\
\hline GM1 (15) & 8 & $9.0 \pm 4.7$ & $209 \pm 42$ & $4.9 \pm 1.3$ & $3.5 \pm 0.8$ & $0.2 \pm 0.1$ & 0 & 0 \\
\hline LIGA20 (15) & 8 & $20 \pm 11^{*}$ & $134 \pm 31^{*}$ & $3.3 \pm 1.8^{*}$ & $1.2 \pm 0.8^{*}$ & 0 & 0 & 0 \\
\hline
\end{tabular}

Animals were injected intraperitoneally with $25 \mathrm{mg} / \mathrm{kg} \mathrm{KA}$. Data (mean \pm SD) were adapted from Figure $4 .{ }^{*} p<0.01$ and ${ }^{* *} p<0.05$, compared with ganglioside-untreated control mice in same genotype group; ${ }^{* * *} p<0.05$, compared with wild-type (ganglioside untreated) animal. Data were analyzed using one-way ANOVA with Dunnett's post test.

Table 2. Statistical analysis of KA-induced seizures in KO mice

\begin{tabular}{|c|c|c|c|c|c|c|c|c|}
\hline \multirow[b]{2}{*}{ Ganglioside (mg/kg) } & \multirow[b]{2}{*}{$n$} & \multirow{2}{*}{$\begin{array}{l}\text { Initiation } \\
\text { (min) }\end{array}$} & \multirow{2}{*}{$\begin{array}{l}\text { Duration } \\
\text { (min) }\end{array}$} & \multirow{2}{*}{$\begin{array}{l}\text { Maximum } \\
\text { seizure score }\end{array}$} & \multicolumn{4}{|c|}{ Seizure score after KA (min) } \\
\hline & & & & & 100 & 200 & 400 & 600 \\
\hline Control & 26 & $10 \pm 5.4$ & $>700^{*}$ & $5.7 \pm 0.3$ & $5.6 \pm 0.6^{*}$ & $4.9 \pm 0.2^{*}$ & $3.3 \pm 0.9^{*}$ & $2.6 \pm 0.6^{*}$ \\
\hline GM1 (1) & 6 & $12 \pm 9.4$ & $>700$ & $5.5 \pm 0.4$ & $5.5 \pm 0.5$ & $4.8 \pm 0.5$ & $3.1 \pm 0.6$ & $2.2 \pm 0.2$ \\
\hline GM1 (5) & 4 & $7.1 \pm 6.5$ & $>700$ & $5.6 \pm 0.3$ & $5.3 \pm 0.7$ & $4.6 \pm 0.7$ & $2.9 \pm 0.5$ & $2.2 \pm 0.6$ \\
\hline GM1 (15) & 6 & $17 \pm 6.5^{* *}$ & $>700$ & $5.2 \pm 1.1$ & $5.2 \pm 0.2$ & $4.6 \pm 0.4$ & $2.0 \pm 0.8^{* * *}$ & $1.4 \pm 0.7^{* * * *}$ \\
\hline GM1 (30) & 5 & $19 \pm 4.3^{* * *}$ & $>700$ & $5.2 \pm 0.6$ & $5.3 \pm 0.5$ & $4.1 \pm 1.0^{* * *}$ & $1.9 \pm 0.7^{* * *}$ & $1.4 \pm 0.5^{* * *}$ \\
\hline LIGA20 (1) & 4 & $17 \pm 5.0$ & $>700$ & $5.4 \pm 0.8$ & $5.4 \pm 0.2$ & $3.4 \pm 1.0^{* * *}$ & $2.5 \pm 1.2$ & $2.3 \pm 0.9$ \\
\hline LIGA20 (2.5) & 15 & $22 \pm 4.7^{* * *}$ & $242 \pm 62^{* * *}$ & $3.9 \pm 1.8^{* * *}$ & $3.3 \pm 0.6^{* * *}$ & $0.5 \pm 0.2^{* * *}$ & $0^{* * *}$ & $0^{* * *}$ \\
\hline LIGA20 (5) & 5 & $7.1 \pm 3.4$ & $>700$ & $4.9 \pm 1.7$ & $4.1 \pm 0.9^{* * *}$ & $2.1 \pm 1.0^{* * *}$ & $1.2 \pm 1.3^{* * *}$ & $1.0 \pm 0.2^{* * *}$ \\
\hline LIGA20 (10) & 5 & $7.2 \pm 2.5$ & $>700$ & $5.9 \pm 0.1$ & $5.9 \pm 0.1$ & $5.4 \pm 0.6$ & $4.5 \pm 0.6^{* * *}$ & $3.9 \pm 0.6^{* * *}$ \\
\hline LIGA20 (15) & 4 & $6.3 \pm 2.0$ & $>700$ & $6.0 \pm 0.1$ & $6.0 \pm 0.2$ & $5.7 \pm 0.4^{* * *}$ & $5.4 \pm 0.9^{* * *}$ & $5.0 \pm 0.7^{* * *}$ \\
\hline
\end{tabular}

Animals were injected intraperitoneally with $25 \mathrm{mg} / \mathrm{kg} \mathrm{KA}$. Data (mean \pm SD) were adapted from Figure $4 .{ }^{*} p<0.01$, compared with wild-type, ganglioside-untreated (control) mice in Table 1 . ${ }^{* *} p<0.05$ and ${ }^{* * *} p<0.01$, compared with control KO mice. Data were analyzed by one-way ANOVA with Dunnett's post-test.

similar protocol provided only borderline protection to CA3 neurons, the 2.82 score in this case being reduced to $2.17(p<0.1)$.

\section{Comparative ability of LIGA 20 and GM1 to enter brain and associate with nuclei}

In this experiment, equivalent amounts of $\left[{ }^{3} \mathrm{H}\right] \mathrm{GM} 1$ and $\left[{ }^{3} \mathrm{H}\right]$ LIGA 20 were separately injected intraperitoneally into five to six WT mice each. Two hours later, the brains were removed, freed of blood and meninges, homogenized, and subjected to differential centrifugation; GM1 and LIGA 20 were each isolated from the subfractions and counted. Comparison of these substances in homogenates revealed four to five times as much LIGA 20 had entered brain as GM1 (Fig. 6A). Significantly more LIGA 20 also entered the various subcellular fractions, which, in view of the paucity of counts in the soluble fraction, represented various membrane structures. In the case of purified nuclei, which contained three to four times as much LIGA 20 as GM1, this likely indicated uptake by NE. Microsomes, containing five to six times as much LIGA 20 as GM1, included PM as well as intracellular membranes. Additional evidence for incorporation into brain was obtained by intraperitoneal injection of unlabeled LIGA 20 into $\mathrm{KO}$ mice, followed by TLC detection of LIGA 20 in extracts of cerebral tissue (Fig. $2 A, B$ ). LIGA 20 was also detected histochemically in such animals via Ctx B-HRP application to hippocampal sections; this revealed membrane staining in both PM and NE of $\mathrm{KO}$ animals (Fig. 2 E, G). LIGA 20 staining was somewhat more diffuse than that of GM1 in hippocampus of untreated WT mice (Fig. 2D,F); the latter also showed clear evidence of GM1 in both PM and NE (Fig. $2 F$ ). Intraperitoneal injection of GM1 into KO mice produced relatively little Ctx B staining in the hippocampus (data not shown), in contrast to intracellular staining that occurred when a high concentration of GM1 was applied to neural cells in culture (Wu et al., 2001b).

\section{Restoration of $\mathrm{Na}^{+} / \mathrm{Ca}^{2+}$ exchange activity in $\mathrm{KO}$ nuclei by LIGA 20}

Measurement of $\mathrm{Na}^{+}$-dependent ${ }^{45} \mathrm{Ca}^{2+}$ uptake by NE of isolated nuclei revealed significantly retarded activity for nuclei from $\mathrm{KO}$ brain (Fig. $6 B, C$ ). In view of the key role previously shown for GM1 in potentiation of $\mathrm{Na}^{+} / \mathrm{Ca}^{2+}$ exchanger activity in NE (Xie et al., 2002), and the above demonstrated ability of LIGA 20 to enter the nucleus, we compared these activities with ${ }^{45} \mathrm{Ca}^{2+}$ uptake in nuclei from LIGA 20 -treated KO mice. Such treatment restored ${ }^{45} \mathrm{Ca}^{2+}$ uptake close to the level for WT nuclei (Fig. 6B,C). Also shown is the control experiment, in which the outer membrane of the NE was removed, thereby destroying the NE as a storage site for $\mathrm{Ca}^{2+}$; the observed low values of ${ }^{45} \mathrm{Ca}^{2+}$ uptake likely reflected remnant NE not destroyed by citrate and/or ${ }^{45} \mathrm{Ca}^{2+}$ entering the nucleoplasm that was not entirely removed by subsequent washing. ${ }^{45} \mathrm{Ca}^{2+}$ uptake by such nuclei was subtracted from ${ }^{45} \mathrm{Ca}^{2+}$ retained by intact nuclei at corresponding choline $/ \mathrm{Na}^{+}$ratios.

\section{Discussion}

Principal findings of this study include demonstration of greatly increased vulnerability of GalNAcT ${ }^{-1-} \mathrm{KO}$ mice to KA-induced seizures and the ability of LIGA 20, a semisynthetic analog of GM1, to attenuate seizure activity when administered intraperitoneally. GM1 itself had only marginal effect on KA-induced seizures in WT and HZT mice but had a more observable effect on the KOs. GM1 is a pluripotent ganglioside known to exert diverse modulatory effects on a variety of membrane receptors, enzymes, ion channels, and adhesion molecules (Kreutter et al., 1987; Doherty et al., 1992; Fueshko and Schengrund, 1992; Carlson et al., 1994; Ferrari et al., 1995; Mutoh et al., 1995; Saito et al., 1995; Wu et al., 1996, 1997; Pitto et al., 1998; Rampersaud et al., 1999; Wang et al., 1999). It was shown to have neuroprotective prop- 
A

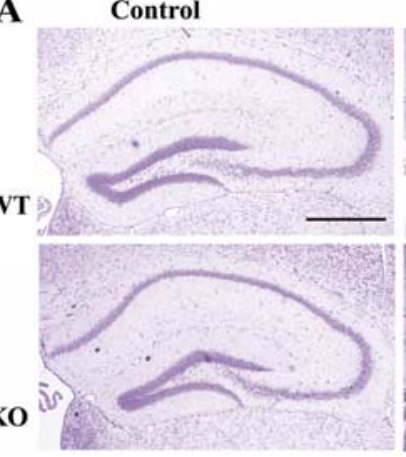

B
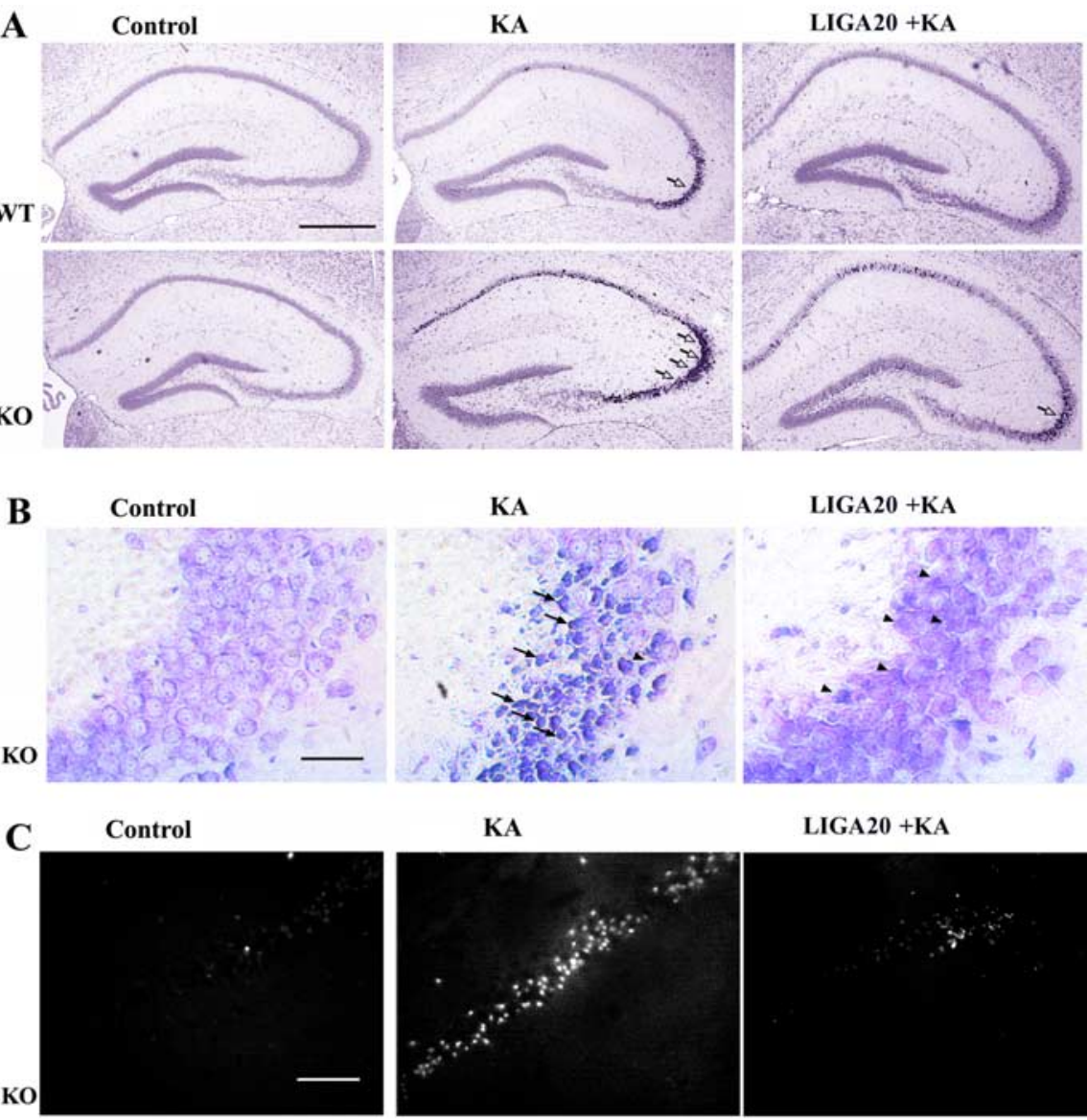

KA
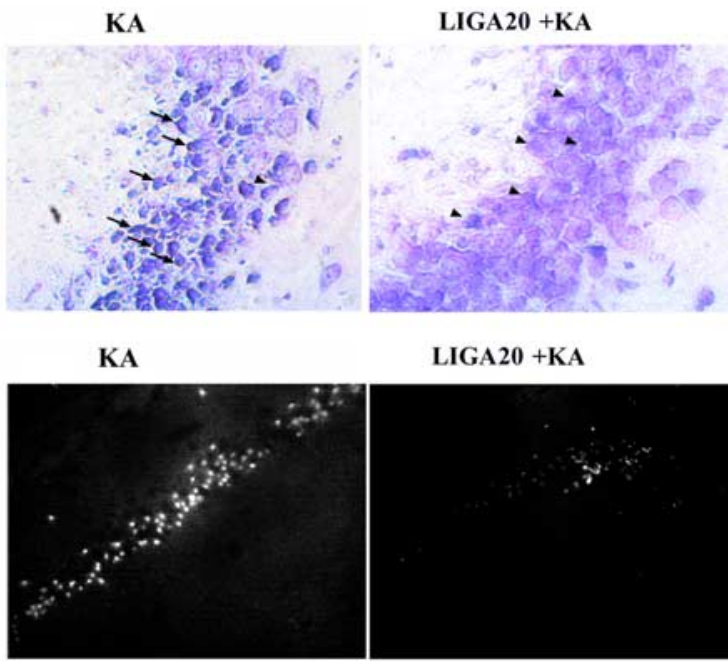

D

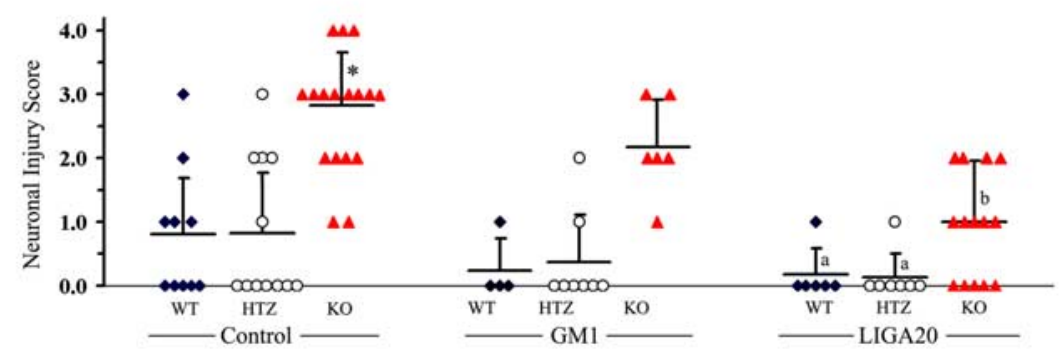

Figure 5. KA-induced neuronal damage in hippocampus. Animals were killed $7 \mathrm{~d}$ after KA $(25 \mathrm{mg} / \mathrm{kg})$ intraperitoneal injection and coronal brain sections through hippocampus were stained with Nissl or TUNEL. A, Low-power Nissl images. KA-induced damage represented by dark spots (arrows) was extensive in CA3 pyramidal layer of KO mice compared with WT. LIGA 20 administered intraperitoneally $2 \mathrm{~h}$ before KA afforded significant protection. Scale bar, $500 \mu \mathrm{m}$. B , Higher-power Nissl images of CA3 region in KO hippocampus. KA treatment induced severe damage to pyramidal neurons: shrunken cell bodies and pyknotic nuclei that were heavily stained (arrows), in association with cell loss. LIGA 20 reduced these indicators of neuronal injury to a modest level (arrowheads). Scale bar, $50 \mu \mathrm{m}$. C, TUNEL staining of CA3 region of KO hippocampus. Apoptosis induced by KA was significantly reduced by LIGA 20. Scale bar, $100 \mu \mathrm{m}$. D, Semiquantification of hippocampal damage. Each symbol represents one animal. Average score ( $\pm S D$ ) in each group is indicated by horizontal line. In control experiments (KA only), KO mice showed significantly higher scores than the other genotypes. LIGA 20 significantly reduced damage in all genotypes, compared with GM1 whose effect was limited. Scoring was as described in Materials and Methods. ${ }^{*} p<0.01$ compared with WT; $a, p<0.01$, and b, $p<0.05$ compared with untreated KA (control) of the same genotype untreated with GM1 or LIGA 20 (one-way ANOVA with Dunnett's post test).

erties in several in vitro and in vivo systems (for review, see Mahadik and Karpiak, 1988; Ledeen, 1989; Skaper et al., 1989). Together with other members of the gangliotetraose family, some of which express modulatory effects toward other proteins ( $\mathrm{Ha}-$ komori and Igarashi, 1993), GM1 increases dramatically as a component of the PM glycocalyx during neuronal differentiation (Ledeen and $\mathrm{Wu}, 1992$ ). Similar elevation of GM1 occurs in the $\mathrm{NE}$ of primary neurons and neuroblastoma cells in association with axonogenesis (Wu et al., 1995a; Kozireski-Chubak et al., 1999a,b,c), and the present study illustrates the neuroprotective aspect of this phenomenon. A deficiency of gangliosides in the GalNAcT ${ }^{-1-}$ $\mathrm{KO}$ mouse resulted in failure to restore $\mathrm{Ca}^{2+}$ homeostasis after intracellular $\mathrm{Ca}^{2+}$ elevation in cultured cerebellar granule neurons (Wu et al., 2001a). That such failure was attributable specifically to GM1 absence was suggested in the finding that cerebellar granule neurons from these mice were rescued to some extent from apoptosis-related excitotoxicity by this ganglioside and more effectively by the LIGA 20 homolog (Wu et al., 2004). Similar findings were made with a mutant cell line lacking GM1 synthase (Wu et al., 2001b).

LIGA 20 is a derivative of GM1 in which the natural long-chain fatty acid (mainly stearate) joined in amide linkage to the 2-amino group of sphingosine is replaced by dichloroacetyl; oligosaccharide and sphingosine moieties remain unchanged (Fig. 1A) (Manev et al., 1990). This derivative retains many of the biological properties of GM1, but the structural change alters its biophysical properties, rendering it less aggregative in forming micelles and more membrane permeant (Perillo et al., 1993). The latter property may account for the superior neuroprotective behavior of LIGA 20 compared with GM1, in particular its ability to enter cells and insert into the NE. This might also explain its ability to transfer from gut to circulatory system and to penetrate the blood-brain barrier when administered orally to rats (Polo et al., 1994). Oral administration of LIGA 20 proved effective in reducing infarct size after cortical thrombosis in rats (Kharlamov et al., 1994) and restoring depressed dopamine levels in MPTP (1-methyl-4-phenyl1,2,3,6-tetrahydropyridine)-treated mice (Schneider and DiStefano, 1993, 1995). The more limited neuroprotection conferred by GM1 in those and other systems correlates with its limited ability to traverse membranes, as seen here in the lower amounts (compared with LIGA 20) entering the CNS (Fig. 6A). Similarly, in neural cell cultures, high concentrations of GM1 were required to force entry into the cell and insertion into the NE, compared with an order of magnitudelower concentration of LIGA 20 needed for similar effect (Wu et al., 2001b, 2004). The fact that GM1 was partially effective in alleviating seizure intensity in $\mathrm{KO}$ mice (Fig. $4 C$ ) may reflect the compromise of the blood-brain barrier during seizure activity.

The physical properties of LIGA 20 that render it more membrane permeant than GM1 may also account for its negative effects at higher concentrations in the kainate-treated $\mathrm{KO}$ mouse 

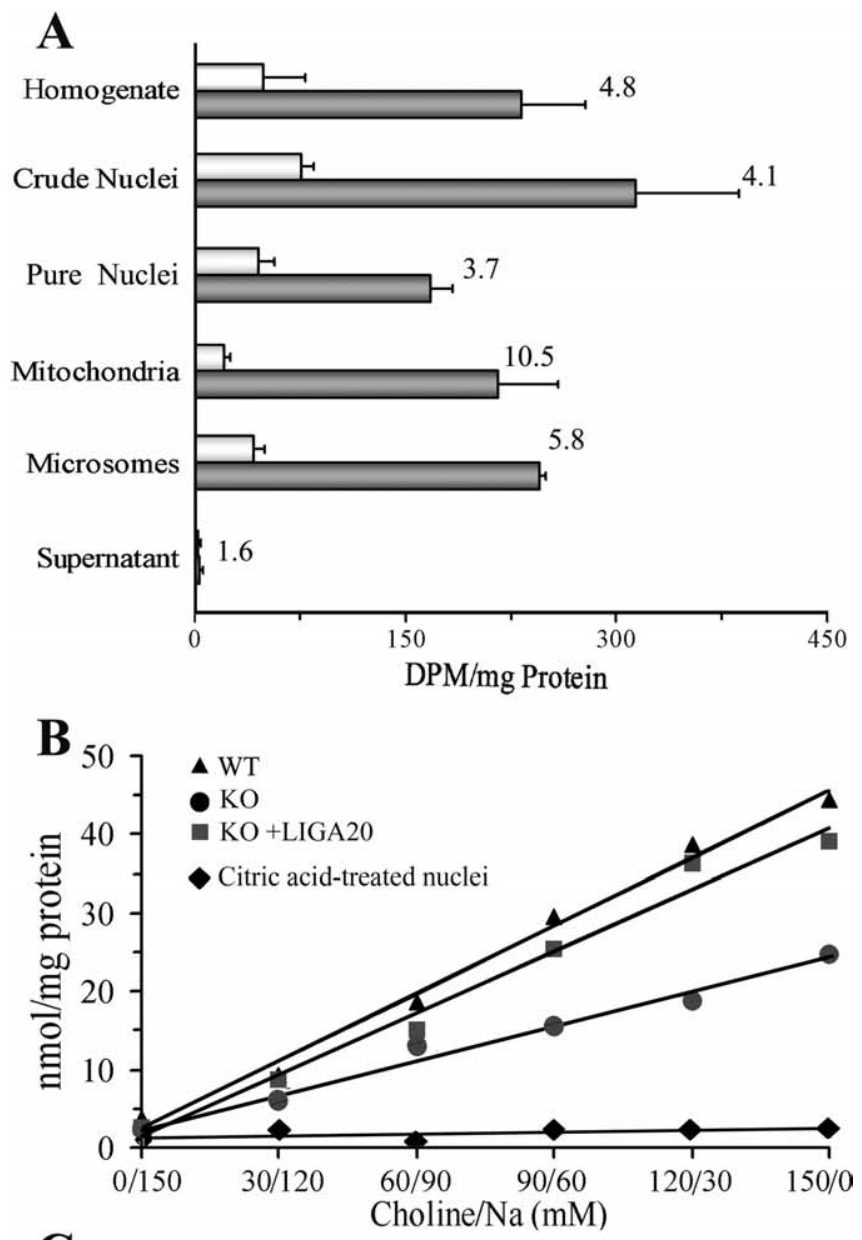

C

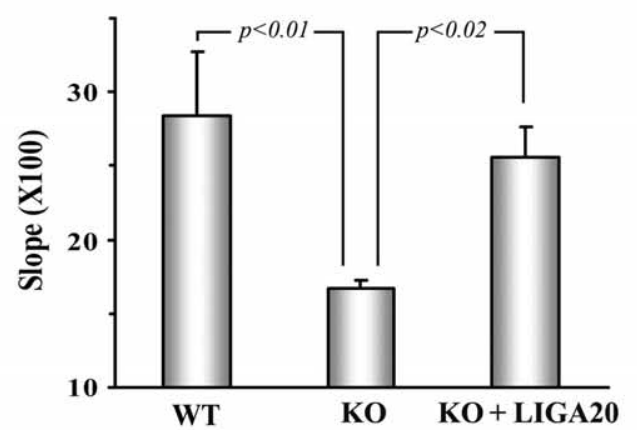

Figure 6. $\boldsymbol{A}$, Incorporation of $\left[{ }^{3} \mathrm{H}\right] \mathrm{GM} 1$ and $\left[{ }^{3} \mathrm{H}\right] \mathrm{LIGA} 20$ into brain membranes. WT mice were injected intraperitoneally with $15 \mathrm{mg} / \mathrm{kg}\left(2 \times 10^{6} \mathrm{dpm}\right)$ per animal of [ $\left.{ }^{3} \mathrm{H}\right] \mathrm{GM} 1$ or $\left[{ }^{3} \mathrm{H}\right]$ LIGA 20. Two hours after injection, five to six brains were pooled and subcellular fractions obtained as described. LIGA 20 (dark bars) and GM1 (light bars) were isolated and counted. Data are average $( \pm S D)$ of three independent experiments. The number accompanying each pair of bars is ratio of LIGA 20 to GM1; $p<0.01$ for all membrane-containing fractions. $\boldsymbol{B}$, Potentiation of $\mathrm{Na}^{+} / \mathrm{Ca}^{2+}$ exchanger by LIGA 20 in nuclei from KO brain. Brain nuclei were isolated and $\mathrm{Na}$-dependent ${ }^{45} \mathrm{Ca}$-uptake into NE lumen was determined as described. Exchange activity of KO nuclei was significantly less than that of WT but was elevated to near normal in nuclei from KO mice treated intraperitoneally with LIGA 20. Also shown is the result with citric acid-treated nuclei which were unable to sequester ${ }^{45} \mathrm{Ca}^{2+}$ in NE lumen because of the removal of the outer membrane of NE. Data are average ( \pm SD) of three independent experiments. $\boldsymbol{C}$, Statistical analysis of data in $\boldsymbol{B}$ using Student's two-tailed $t$ test.

(Fig. 4D). Lysolipids in general are known to be lytic at higher concentrations, and replacement of the long-chain fatty acid gives a structure approaching that of a lysoganglioside. Similar detrimental effects of LIGA 20 at higher concentrations were ob- served in cell culture studies (Manev et al., 1990; Wu et al., 2001b), whereas exogenously applied GM1 did not show such effects either in vitro or in vivo.

The rationale for proposing that insertion of LIGA 20 into the $\mathrm{NE}$ is essential for restoring nuclear $\mathrm{Ca}^{2+}$ homeostasis is based on the presence of an $\mathrm{Na}^{+} / \mathrm{Ca}^{2+}$ exchanger in the NE that is dependent on GM1 (or its homolog) for optimal activity; this was demonstrated in neurons and neuronal cell lines (Xie et al., 2002) as well as certain non-neural cells (Xie et al., 2004a,b). Those studies revealed the NE exchanger to bind GM1 with unusually high affinity (surviving SDS-PAGE) and to be situated at the inner membrane of the NE. The outer membrane of this doublemembrane structure is continuous with the ER membrane and hence the NE lumen is continuous with the ER lumen, thereby providing a storage site for a significant portion of nuclear $\mathrm{Ca}^{2+}$ (Thomas et al., 1992; Petersen et al., 1998). The GM1-exchanger complex is thus situated to mediate $\mathrm{Ca}^{2+}$ transfer between nucleoplasm and NE, which might well provide the basis of its neuroprotective function. The occurrence of $\mathrm{Na}^{+} / \mathrm{Ca}^{2+}$ exchangerGM1 complexes in the NE of neural and non-neural cells suggests a widespread protective mechanism in vertebrate cells against the potentially harmful effects of excessive intracellular $\mathrm{Ca}^{2+}$. The inner membrane of the $\mathrm{NE}$ is also equipped with $\operatorname{Ins}(1,4,5) \mathrm{P}_{3}$ (inositol triphosphate) receptors that mediate release of $\mathrm{Ca}^{2+}$ into nucleoplasm (Humbert et al., 1996). By moving $\mathrm{Ca}^{2+}$ in the opposite direction, the nuclear exchanger would function in a manner analogous to the similar exchanger in the PM, promoting uphill transfer of $\mathrm{Ca}^{2+}$ against a steep gradient. This is a $\mathrm{Na}^{+}$driven process, consistent with the presence of a $\mathrm{Na}^{+} / \mathrm{K}^{+}$ATPase in the NE that maintains high $\mathrm{Na}^{+}$in that lumen (Garner, 2002). The properties of nuclear $\mathrm{Na}^{+} / \mathrm{Ca}^{2+}$ exchanger isoforms were shown to differ in some respects from those of the PM isoforms, including tight association with GM1 for the former (Xie et al., 2002, 2004a,b). The presence of nuclear pore complexes throughout the NE are thought to permit free passage of $\mathrm{Ca}^{2+}$ between cytosol and nucleoplasm, thereby promoting equilibration of $\mathrm{Ca}^{2+}$ in the nucleoplasm with that in the cytosol (Bootman et al., 2000). However, some studies have suggested the possibility of independent regulation of nuclear $\mathrm{Ca}^{2+}$ (AlMohanna et al., 1994; Hardingham et al., 1997; Badminton et al., 1998), and the presence of nuclear $\mathrm{Na}^{+} / \mathrm{Ca}^{2+}$ exchange activity would appear to support that view. Additional work is needed to fully clarify this issue.

That nuclear $\mathrm{Ca}^{2+}$ regulation is mediated, at least in part, by the exchanger-GM1 complex of the NE is suggested in the current observation that exchanger activity of nuclei from $\mathrm{KO}$ brain was significantly less than that of WT nuclei and could be restored to near-normal level (Fig. 6B,C) along with attenuation of seizures (Fig. 4D) by LIGA 20. There may be additional mechanisms by which GM1 and LIGA 20 could protect against the harmful effects of the $\mathrm{Ca}^{2+}$ dysregulation accompanying glutamate excitotoxicity, with some evidence suggesting mechanisms located in the PM (Vaccarino et al., 1987; Favaron et al., 1988; Manev et al., 1990). This might account for the beneficial effect of LIGA 20 on seizure activity in normal mice, although such benefit was less pronounced than with KO mice (Table 1, Fig. 4). Previous studies tended to implicate the presence of endogenous GM1 as a barrier to seizure activity, e.g., those showing epileptogenesis in rat brain induced by GM1-blocking agents such as anti-GM1 antibody (Rapport et al., 1979) and Ctx B (Karpiak et al., 1978). Application of exogenous gangliosides to animal models of epilepsy gave variable results involving no effect (Albertson and Walby, 1987), negative effect (Nakamura et al., 1989), or mildly positive effect 
on seizure-induced memory deficit (Grecksch et al., 1991). As mentioned, the fact that exogenously applied gangliosides have limited ability to reach the nucleus might explain their failure to show the effects achieved here with LIGA 20. Study of ganglioside changes associated with temporal lobe epilepsy in the human hippocampus revealed a loss of GD1a (disialo analog of GM1) that was attributed to neuronal destruction and an increase in GD3 (a nongangliotetraose ganglioside) that was attributed to localized accumulation of reactive glia (Yu et al., 1987). It is well recognized that seizure activity is a complex process (Seyfried et al., 1979; Engel et al., 1997; Buckmaster et al., 2002) and that ganglioside changes are not the sole cause or result of such pathology.

Although the initial studies of GalNAcT ${ }^{-1-} \mathrm{KO}$ mice showed negligible phenotype at relatively young age (Takamiya et al., 1996), subsequent examination of similar mice revealed axonal degeneration and decreased myelination (Sheikh et al., 1999). A follow-up study reported development of significant and progressive behavioral neuropathies with aging (Chiavegatto et al., 2000). In a similar vein, we observed such mice to show significantly shortened average lifespan approximating 1 year or less compared with 2-3 years for WT; in addition, and of relevance to the present study, we found the KOs highly susceptible to audiogenic seizures independent of KA administration (G. Wu and R. Ledeen, unpublished observations). A possible connection of this $\mathrm{KO}$ model to the human condition was suggested in the report of infantile-onset symptomatic epilepsy syndrome observed in a child with mutated GM3 synthase (Simpson et al., 2004). Double-mutant mice with disrupted GM2/GD2 synthase and GD3 synthase genes, which express GM3 as their major ganglioside and none of the gangliotetraose family, displayed a sudden death phenotype with high susceptibility to lethal audiogenic seizures (Kawai et al., 2001). In contrast, the single GD3 synthase $\mathrm{KO}$, which lacked the b-series gangliosides but retained the a-series gangliosides (GM1, GD1a), had a normal lifespan with no overt phenotype (Kawai et al., 2001). These findings are consonant with GM1 being the crucial ganglioside in this form of $\mathrm{Ca}^{2+}$ regulation with attendant neuroprotection. The fact that the KA rodent model of epilepsy has been described as resembling human temporal lobe epilepsy in certain key features (BenAri and Cossart, 2000) makes it a potentially useful system for study in conjunction with mice possessing genetically altered brain ganglioside patterns.

\section{References}

Albertson TE, Walby WF (1987) The effect of exogenous GM1 ganglioside on kindled-amygdaloid seizures. Neuropharmacology 26:261-264.

Al-Mohanna FA, Caddy KWT, Bolsover SR (1994) The nucleus is insulated from large cytosolic calcium ion changes. Nature 367:745-750.

Badminton MN, Kendall JM, Rembold CM, Campbell AK (1998) Current evidence suggests independent regulation of nuclear calcium. Cell Calcium 23:79-86.

Ben-Ari Y, Cossart R (2000) Kainate, a double agent that generates seizures: two decades of progress. Trends Neurosci 23:580-587.

Bootman MD, Thomas D, Tovey SC, Berridge MJ, Lipp P (2000) Nuclear calcium signalling. Cell Mol Life Sci 57:371-378.

Buckmaster PS, Otero-Corchon V, Rubinstein M, Low MJ (2002) Heightened seizure severity in somatostatin knockout mice. Epilepsy Res 48:43-56.

Carlson RO, Masco D, Brooker G, Spiegel S (1994) Endogenous ganglioside GM1 modulates L-type calcium channel activity in N18 neuroblastoma cells. J Neurosci 14:2272-2281.

Chiavegatto S, Sun J, Nelson RJ, Schnaar RL (2000) A functional role for complex gangliosides: motor deficits in GM2/GD2 synthase knockout mice. Exp Neurol 166:227-234.
Choi D (1994) Calcium and excitotoxic neuronal injury. Ann NY Acad Sci 747:162-171.

De Erausquin GA, Manev H, Guidotti A, Costa E, Brooker G (1990) Gangliosides normalize distorted single-cell intracellular free $\mathrm{Ca}^{2+}$ dynamics after toxic doses of glutamate in cerebellar granule cells. Proc Natl Acad Sci USA 87:8017-8021.

Doherty P, Ashton SV, Skaper SD, Leon A, Walsh FS (1992) Ganglioside modulation of neural cell adhesion molecule and $\mathrm{N}$-cadherin-dependent neurite outgrowth. J Cell Biol 117:1093-1099.

Engel Jr J, Williamson PD, Wieser H-G (1997) Mesial temporal lobe epilepsy. In: Epilepsy: a comprehensive textbook. (Engel Jr J, Pedley TA, eds), pp 2417-2426. Philadelphia: Lippincott-Raven.

Favaron M, Manev H, Alho H, Bertolino M, Ferret B, Guidotti A, Costa E (1988) Gangliosides prevent glutamate and kainate neurocytoxicity in primary neuronal cultures of neonatal rat cerebellum and cortex. Proc Natl Acad Sci USA 85:7351-7355.

Ferrari G, Anderson BL, Stephens RM, Kaplan DR, Greene LA (1995) Prevention of apoptotic neuronal death by GM1 ganglioside. Involvement of Trk neurotrophin receptors. J Biol Chem 270:3074-3080.

Folch J, Lees M, Sloane Stanley GH (1957) A simple method for the isolation and purification of total lipids from animal tissues. J Biol Chem 226:497-509.

Fueshko SM, Schengrund C-L (1992) Identification of a GM1-binding protein on the surface of murine neuroblastoma cells. J Neurochem 59:527-535.

Garner MH (2002) Na,K-ATPase in the nuclear envelope regulates $\mathrm{Na}^{+}$: $\mathrm{K}^{+}$gradients in hepatocyte nuclei. J Membr Biol 187:97-115.

Gilchrist JC, Pierce GN (1993) Identification and purification of a calciumbinding protein in hepatic nuclear membranes. J Biol Chem 268:4291-4299.

Grecksch G, Becker A, Gadau C, Matthies H (1991) Gangliosides improve a memory deficit in pentylenetetrazol-kindled rats. Pharmacol Biochem Behav 39:825-828.

Hakomori S, Igarashi Y (1993) Gangliosides and glycosphingolipids as modulators of cell growth, adhesion, and transmembrane signaling. Adv Lipid Res 25:147-162.

Hardingham GE, Chawla S, Johnson CM, Bading H (1997) Distinct functions of nuclear and cytoplasmic calcium in the control of gene expression. Nature 385:260-265.

Humbert JP, Matter N, Artault JC, Koppler P, Malviya AN (1996) Inositol 1,4,5-trisphosphate receptor is located to the inner nuclear membrane vindicating regulation of nuclear calcium signaling by inositol 1,4,5trisphosphate. Discrete distribution of inositol phosphate receptors to inner and outer nuclear membranes. J Biol Chem 271:478-485.

Karpiak SE, Mahadik SP, Rapport MM (1978) Ganglioside receptors and induction of epileptiform activity: cholera toxin and choleragenoid (B subunits). Exp Neurol 62:256-259.

Kawai H, Allende ML, Wada R, Kono M, Sango K, Deng C, Miyakawa T, Crawley JN, Werth N, Bierfreund U, Sandhoff K, Proia R (2001) Mice expressing only monosialoganglioside GM3 exhibit lethal autiogenic seizures. J Biol Chem 276:6885-6888.

Kharlamov A, Zivkovic I, Polo A, Armstrong DM, Costa E, Guidotti A (1994) LIGA20, a lyso derivative of ganglioside GM1, given orally after cortical thrombosis reduces infarct size and associated cognition deficit. Proc Natl Acad Sci USA 91:6303-6307.

Kozireski-Chubak DF, Wu G, Ledeen RW (1999a) Axonogenesis in Neuro-2a cells correlates with GM1 upregulation in the nuclear and plasma membranes. J Neurosci Res 57:550.

Kozireski-Chubak DF, Wu G, Ledeen RW (1999b) Developmental appearance of nuclear GM1 in neurons of the central and peripheral nervous systems. Dev Brain Res 115:201-208.

Kozireski-Chubak DF, Wu G, Ledeen RW (1999c) Upregulation of nuclear GM1 accompanies axon-like, but not dendrite-like, outgrowth in NG108-15 cells. J Neurosci Res 55:107-118.

Kreutter D, Kim JYH, Goldenring JR, Rasmussen H, Ukomadu C, DeLorenzo RJ, Yu RK (1987) Regulation of protein kinase C activity by gangliosides. J Biol Chem 262:1633-1637.

Ledeen RW (1989) Biosynthesis, metabolism, and biological effects of gangliosides. In: Neurobiology of glycoconjugates (Margolis RU, Margolis RK, eds), pp 43-83. New York: Plenum.

Ledeen RW, Wu G (1992) Ganglioside function in the neuron. Trends Glycosci Glycotechnol 4:174-187. 
Ledeen RW, Wu G (2002) Ganglioside function in calcium homeostasis and signaling. Neurochem Res 27:637-647.

Ledeen RW, Yu RK (1982) Gangliosides: structure, isolation, and analysis. Methods Enzymol 83:139-191.

Ledeen RW, Wu G, Lu Z-H, Kozireski-Chuback D, Fang Y (1998) The role of GM1 and other gangliosides in neuronal differentiation. Ann NY Acad Sci 845:161-175.

Ledeen RW, Wang J, Lu Z, Wang Y, Meyenhofer MF, Wu G (2004) Heightened kainate-induced seizures in ganglioside-deficient $(\mathrm{KO})$ mice: function of GM1 in neuronal calcium homeostasis. J Neurochem 90 [Suppl 1]:90.

Leskawa KC, Dasgupta S, Chien J-L, Hogan EL (1984) A simplified procedure for the preparation of the tritiated GM1 ganglioside and other glycosphingolipids. Anal Biochem 140:172-177.

Liu Y, Wada R, Kawai H, Sango K, Deng C, Tai T, McDonald MP, Araujo K, Crawley JN, Bierfreund U, Sandhoff K, Suzuki K, Proia RL (1999a) A genetic model of substrate deprivation therapy for a glycosphingolipid storage disorder. J Clin Invest 103:497-505.

Liu H, Cao Y, Basbaum AI, Mazarati AM, Sankar R, Wasterlain CG (1999b) Resistance to excitotoxin-induced seizures and neuronal death in mice lacking the preprotachykinin A gene. Proc Natl Acad Sci USA 96:12096-12101.

Mahadik SP, Karpiak SE (1988) Gangliosides in treatment of neural injury and disease. Drug Dev Res 15:337-360.

Manev H, Favaron M, Vicini S, Guidotti A, Costa E (1990) Glutamateinduced neuronal death in primary cultures of cerebellar granule cells: protection by synthetic derivatives of endogenous sphingolipids. J Pharmacol Exp Ther 252:419-427.

Manev H, Guidotti A, Costa E (1993) Protection by gangliosides against glutamate excitotoxicity. Adv Lipid Res 25:269-285.

Meldrum B, Garthwaite J (1990) Excitatory amino acid neurotoxicity and neurodegenerative disease. Trends Pharmacol Sci 11:379-387.

Mutoh T, Tokuda A, Miyadai T, Hamaguchi M, Fujiki N (1995) Ganglioside GM1 binds to the Trk protein and regulates receptor function. Proc Natl Acad Sci USA 92:5087-5091.

Nadler JV (1981) Minireview. Kainic acid as a tool for the study of temporal lobe epilepsy. Life Sci 29:2031-2042.

Nakamura Y, Morimoto K, Okamoto M (1989) Modification of amygdala kindling by intracerebroventricularly administered gangliosides in rats. Exp Neurol 106:61-69.

Perillo MA, Polo A, Guidotti A, Costa E, Maggio B (1993) Molecular parameters of semisynthetic derivatives of gangliosides and sphingosine in monolayers at the air-water interface. Chem Phys Lipids 65:225-238.

Petersen OH, Gerasimenko OV, Gerasimenko JV, Mogami H, Tepikin AV (1998) The calcium store in the nuclear envelope. Cell Calcium 23:87-90.

Pitto M, Mutoh T, Kuriyama M, Ferraretto A, Palestini P, Masserini M (1998) Influence of endogenous GM1 ganglioside on TrkB activity, in cultured neurons. FEBS Lett 439:93-96.

Polo A, Kirschner G, Guidotti A, Costa E (1994) Brain content of glycosphingolipids after oral administration of monosialogangliosides GM1 and LIGA20 to rats. Mol Chem Neuropathol 21:41-53.

Rampersaud AA, Oblinger JL, Ponnappan RK, Burry RW, Yates AJ (1999) Gangliosides and growth factor receptor regulation. Biochem Soc Trans 27:415-422.

Rapport MM, Karpiak SE, Mahadik SP (1979) Biological activities of antibodies injected into brain. Fed Proc 38:2391-2396.

Saito M, Frielle T, Benovic JL, Ledeen RW (1995) Modulation by GM1 ganglioside of $\beta_{1}$-adrenergic receptor -induced cyclic AMP formation in Sf9 cells. Biochim Biophys Acta 1267:1-5.

Schneider J, DiStefano L (1993) LIGA 20 increases striatal dopamine levels in aged MPTP-treated mice refractory to GM1 ganglioside treatment. NeuroReport 5:103-104.

Schneider J, DiStefano L (1995) Response of the damaged dopamine system to GM1 and semisynthetic gangliosides: effects of dose and extent of lesion. Neuropharmacology 34:489-493.
Seyfried TN, Glaser GH, Yu RK (1979) Thyroid hormone influence on the susceptibility of mice to audiogenic seizures. Science 205:598-600.

Sheikh KA, Sun J, Liu Y, Kawai H, Crawford TO, Proia RL, Griffin JW, Schnaar RL (1999) Mice lacking complex gangliosides develop Wallerian degeneration and myelination defects. Proc Natl Acad Sci USA 96:7532-7537.

Simpson MA, Cross H, Proukakis C, Priestman DA, Neville DC, Reinkensmeier G, Wang H, Wiznitzer M, Gurtz K, Verganelaki A, Pryde A, Patton MA, Dwek RA, Butters TD, Platt FM, Crosby AH (2004) Infantile-onset symptomatic epilepsy syndrome caused by a homozygous loss-offunction mutation of GM3 synthase. Nat Genet 36:1225-1229.

Skaper SD, Leon A, Toffano G (1989) Ganglioside function in the development and repair of the nervous system. Mol Neurobiol 3:173-199.

Svennerholm L (1964) The gangliosides. J Lipid Res 5:145-155.

Takamiya K, Yamamoto A, Furukawa K, Yamashiro S, Shin M, Okada M, Fukumoto S, Haraguchi M, Takeda N, Fujimura K, Sakae M, Kishikawa M, Shiku H, Furukawa K, Aizawa S (1996) Mice with disrupted GM2/ GD2 synthase gene lack complex gngliosides but exhibit only subtle defects in their nervous system. Proc Natl Acad Sci USA 93:10662-10667.

Thomas AP, Renard DC, Rooney TA (1992) Spatial organization of $\mathrm{Ca}^{2+}$ signalling and $\operatorname{Ins}(1,4,5) \mathrm{P}_{3}$ action. Adv Second Messenger Phosphoprotein Res 26:225-263.

Vaccarino F, Guidotti A, Costa E (1987) Ganglioside inhibition of glutamate-mediated protein kinase $\mathrm{C}$ translocation in primary cultures of cerebellar neurons. Proc Natl Acad Sci USA 84:8707-8711.

Wang Y, Tsui Z, Yang F (1999) Antagonistic effect of ganglioside GM1 and GM3 on the activity and conformation of sarcoplasmic reticulum $\mathrm{Ca}^{2+}$ ATPase. FEBS Lett 457:144-148.

Wu G, Ledeen RW (1988) Quantification of gangliotetraose gangliosides with cholera toxin. Anal Biochem 173:368-375.

Wu G, Lu Z, Ledeen RW (1995a) Induced and spontaneous neuritogenesis are associated with enhanced expression of ganglioside GM1 in the nuclear membrane. J Neurosci 15:3739-3746.

Wu G, Lu Z, Ledeen RW (1995b) GM1 ganglioside in the nuclear membrane modulates nuclear calcium homeostasis during neurite outgrowth. J Neurochem 64:1419-1422.

Wu G, Lu Z, Ledeen RW (1996) GM1 ganglioside modulates prostaglandin E1 stimulated adenylyl cyclase in Neuro-2A cells. Glycoconj J 13:235-239.

Wu G, Lu Z, Ledeen RW (1997) Interaction of $\delta$-opioid receptor with GM1 ganglioside: conversion from inhibitory to excitatory mode. Mol Brain Res 44:341-346.

Wu G, Xie X, Lu Z, Ledeen RW (2001a) Cerebellar neurons lacking complex gangliosides degenerate in the presence of depolarizing levels of potassium. Proc Natl Acad Sci USA 98:307-312.

Wu G, Lu Z, Xie X, Li L, Ledeen RW (2001b) Mutant NG108-15 cells (NGCR72) deficient in GM1 synthase respond aberrantly to axonogenic stimuli and are vulnerable to calcium-induced apoptosis: they are rescued with LIGA-20. J Neurochem 76:690-702.

Wu G, Lu Z, Xie X, Ledeen RW (2004) Susceptibility of cerebellar granule neurons from GM2/GD2 synthase-null mice to apoptosis induced by glutamate excitotoxicity and elevated KCl: rescue by GM1 and LIGA20. Glycoconj J 21:303-311.

Xie X, Wu G, Lu Z, Ledeen RW (2002) Potentiation of sodium-calcium exchanger in the nuclear envelope by nuclear GM1 ganglioside. J Neurochem 81:1185-1195.

Xie X, Wu G, Ledeen RW (2004a) C6 cells express a sodium-calcium exchanger/GM1 complex in the nuclear envelope but have no exchanger in the plasma membrane: comparison to astrocytes. J Neurosci Res 76:363-375.

Xie X, Wu G, Lu Z, Rohowsky-Kochan C, Ledeen RW (2004b) Presence of sodium-calcium exchanger/GM1 complex in the nuclear envelope of non-neural cells: nature of exchanger-GM1 interaction. Neurochem Res 29:2135-2146.

Yu RK, Holley JA, Macala LJ, Spencer DD (1987) Ganglioside changes associated with temporal lobe epilepsy in the human hippocampus. Yale J Biol Med 60:107-117. 